\title{
Local disease concepts relevant to the design of a community-based surveillance program for influenza in rural Guatemala
}

\author{
Alejandro Cerón ${ }^{1,2^{*}}$, Maria Renee Ortiz ${ }^{1}$, Danilo Álvarez ${ }^{1}$ Guy H. Palmer ${ }^{3}$ and Celia Cordón-Rosales ${ }^{1}$
}

\begin{abstract}
Background: Early detection of emergent influenza strains is a global health priority. However, maintaining active surveillance is economically and logistically challenging. While community-based surveillance is an attractive alternative, design and operation of an effective epidemiological surveillance program requires community engagement that can be linked to public health reporting and response. We report the results of a study in rural Guatemalan communities aimed at identifying opportunities for and barriers to community engagement in disease surveillance.

Methods: Using an ethnographic approach followed by a descriptive cross-sectional survey, we documented local terms and ideas about animal illnesses, including the possibility of animal-human transmission.

Results: The community perceived disease causation principally in terms of changes in the physical environment and weather and categorized illnesses using local terminology based on observable clinical signs. Knowledge about prevention and treatment was derived predominantly from local networks of family and friends without evidence of professionally-based knowledge being regularly introduced into the community.

Conclusions: Bridging the divide between professional and community-based descriptive disease terminology, incorporating animal and human health responsiveness to common illnesses, and providing professional knowledge into the community-based networks were identified as addressable challenges to effective implementation of community-based surveillance.
\end{abstract}

Keywords: Surveillance, Epidemiologic Surveillance, Community Participation, Influenza in humans, Influenza in birds, Zoonosis, Guatemala

\section{Background}

Early detection of emergent influenza strains is a global health priority. Environments where wildlife is in close contact with domestic animals and humans are considered hotspots for the emergence of potentially pathogenic influenza strains [1-5]. The 2009 H1N1 virus responsible for the most recent pandemic contained genetic material derived from both avian and swine viruses and zoonotic transmission of the highly pathogenic avian $\mathrm{H} 5 \mathrm{~N} 1$ to humans resulted in an abnormally high

\footnotetext{
* Correspondence: alejandro.ceronvaldes@du.edu

${ }^{1}$ Center for Health Studies, Universidad del Valle de Guatemala, Guatemala City, Guatemala

${ }^{2}$ Department of Anthropology, University of Denver, Sturm Hall Room 131, 2000 E. Asbury Ave, Denver, CO 80208, USA

Full list of author information is available at the end of the article
}

case fatality rate [6, 7]. Notably, the H5N1 global spread was linked to movement of birds, both domestic poultry and migratory waterfowl [8-11]. Correspondingly, an increase in surveillance, especially in more vulnerable countries and populations where multiple animal species interact in close proximity to humans has been called for and, to varying degrees of success, implemented [1214]. However maintaining active surveillance, especially in low income countries and communities where poultry and livestock are predominately raised in the absence of biosecurity and in close proximity to households, is both economically and logistically challenging given other pressing health and non-health priorities. An alternative approach is a community-based surveillance program in which the community itself is responsible for detecting 
changes in disease patterns in their livestock and poultry, understanding the risk of zoonotic transmission, and empowered to alert regional and national health authorities [15-17].

Community participation is essential for the design of efficient epidemiological surveillance programs. The systematic use of research methods applied to epidemiological programs facilitates the documentation of community understandings of disease and options for disease control. This type of research emphasizes community involvement in defining and prioritizing healthrelated problems, with the goal of improving detection, reporting, and response [18-20]. Participatory epidemiology [21] has been used to address zoonotic disease emergence, transmission, and control [22-28], including for avian influenza [16, 29-31]. As part of this, understanding how a community conceptualizes disease in their animals, assesses prevalence and categorizes specific diseases and patterns, and seeks both animal and human health guidance and treatment are essential.

Communities along Guatemala's southern Pacific coast represent populations that are socioeconomically and epidemiologically vulnerable. Candelaria and Monterrico are the two main towns in the coast of the municipality of Taxisco, where $66 \%$ of residents live in poverty and $18 \%$ in extreme poverty [32], $44 \%$ do not have access to safe sources of water or sanitary services [33], $25 \%$ have no formal education, and $60 \%$ only have some primary education [33, 34]. Predominately rural, families raise domestic animals for household consumption or as an income source. Poultry (predominately chickens and ducks) and swine are free ranging with frequent interactions among these species and with family members. Even if maintained with informal enclosures, poultry and pigs are closely located to the house and linked to the household through free-ranging dogs and cats and a contaminated environment. These free range and high contact rate conditions provide the opportunity to introduce new pathogens or pathogen strains into different animal hosts and humans that would not occur in other ecosystems where potential hosts are physically separated. Specifically free ranging household swine may have a critical role as they have frequently served as intermediate hosts for genetic reassortment of avian influenza viruses, resulting in strains transmissible to and pathogenic for humans $[1,3]$. In addition to the role of free ranging household livestock, the Taxisco coast is a major overwintering zone for migratory aquatic birds: two natural reserves, Monterrico (2,800 ha) and Hawaii (3,657 ha) are large mangrove wetlands [35, 36]. Due to the close and frequent interactions between aquatic migratory fowl, domestic poultry and swine, and humans, these communities are potential hot spots for emergence and spread of influenza.
The Centro de Estudios en Salud de la Universidad del Valle de Guatemala, in collaboration with the U.S. Centers for Disease Control and Prevention, has conducted active surveillance for influenza in Taxisco, focused on these two communities directly bordering the Pacific Ocean, Monterrico and Candelaria [35]. Concomitantly, we initiated a study to identify opportunities for and barriers to community engagement in sustainable community-based surveillance. Using an ethnographic approach followed by a descriptive cross-sectional survey, we documented the characteristics of the main animal illnesses as defined by the community, as well as their signs, perceived causes, and consequent healthseeking behaviors. We report the findings of the study and present them in context of how community-based understanding of disease can be linked to improved public health reporting.

\section{Methods \\ Research design}

The study consisted of two phases. The first phase was exploratory and aimed at identifying the repertoire of local terms, concepts and practices relevant to animal health. The ethnographic approach used in this phase included informal interviews and observations, followed by qualitative analysis [37, 38]. The second phase was descriptive and aimed at documenting the extent to which the local terms, concepts and practices identified in the first phase were used by a representative sample of households. This phase used a cross-sectional survey and descriptive statistics [38]. Study design, data collection, and data analysis were all conducted in Spanish, the local language in the two villages. All authors and a research assistant are native speakers of Spanish, with the exception of GP, who is also fluent.

\section{Population and sample}

The study was carried out in two villages, Monterrico and Candelaria, surrounding the Chiquimulilla Channel wetlands in the Pacific shore of Guatemala. This region was selected because it is an overwintering destination for migratory birds and household livestock include pigs, ducks, and chickens. There are twelve villages in this region, where domestic animals are in contact with the migratory fowl. The two selected villages are the ones with health posts staffed by the Ministry of Human Health, therefore considered to have greater potential for the future implementation of an epidemiological surveillance pilot program.

The ethnographic portion of the study used purposive sampling for selecting individuals with knowledge about animal illnesses and care (i.e. animal owners, healers), as well as places where animal care was delivered (i.e. backyards, kitchens). The cross-sectional survey was 
conducted in a sample of 90 households (42 in Monterrico and 48 in Candelaria) previously selected to randomly sample swine and duck populations as part of an active surveillance program. Monterrico and Candelaria have a total combined population of 961 inhabitants, and a total of 341 households according to a February 2013 census.

\section{Data collection}

An initial phase of ethnographic research was conducted between February and April 2013. This phase consisted of observations and informal interviews conducted by a single interviewer (MRO) oriented by an observation and interview guide [37] aimed at identifying the local terms for household animal illnesses, as well as understanding the local beliefs and practices related to each of those illnesses as associated with care seeking behaviors. Species of interest for this ethnographic phase were chickens, ducks, and swine. Data from observations and informal interviews were documented in notebooks by the interviewer and transcribed into Microsoft Word. MRO and AC cross-checked transcriptions for accuracy and qualitatively analyzed them to identify relevant local terms and concepts..

A subsequent phase of cross-sectional survey was conducted in June 2013. The questionnaire design was informed by the findings of the ethnographic phase, and one questionnaire was administered per household. The questionnaire consisted of close-ended questions organized in six sections. An initial section was aimed at establishing prevalence of illness in the previous 15 days. If illness was reported, subsequent sections investigated name of illness, signs, perceived causes, treatments, and help sought by animal caregivers. Species of interest for this survey were chickens, ducks and swine. The questionnaire was created as an electronic form installed in a tablet computer, checked for accuracy by a field supervisor, and uploaded to a database that generated an Excel spreadsheet used for analysis. The questionnaire was validated by interviewing 10 households with the aim of detecting comprehension problems and to assess if the questions responded to the research aims.

\section{Data analysis}

For the ethnographic phase, MRO and AC analyzed the original field notes and synthesized the findings into profile matrices for each of the reported illnesses. These matrices allowed organization of the information according to signs, perceived causes, treatments, and people/ places sought for help. Matrices identified knowledge gaps to be addressed through additional interviews, and provided means for better understanding each of the illnesses as well as making comparisons between illnesses. Survey data displayed in a Microsoft Excel spreadsheet were analyzed using the pivot tables feature for generating tables of frequencies/percentages and cross tabulation analysis [38].

\section{Ethics, consent and permissions}

The study protocol was approved by the Universidad del Valle de Guatemala's Ethical Review Committee (protocol number 079-04-2013). All participants gave written informed consent. To preserve participants' anonymity, neither the fieldnotes nor the survey documented household or individual identifiers.

\section{Results}

\section{Animal ownership}

A total of 55 informal interviews and 30 observations were documented through the ethnographic phase of the study, and a total of 90 households took part in the cross-sectional survey, with an average of five inhabitants per household (range 1-15). Ownership of animals, transportation assets, and education levels are provided in Table 1.

\section{Described illnesses, perceived causes, and treatments as identified by ethnographic research}

Illnesses of chickens, ducks, and swine were specifically described (Table 2). Chicken illnesses include two with predominantly respiratory signs, (coriza and soco, the latter of which was also described as pujo or moco); two with gastrointestinal signs (accidente por abajo and cólera), two with problems of locomotion (polio or apolio and calambres), one with cutaneous signs (viruela or buba), and one with non-specific signs (accidente por arriba). Participants reported that common illness signs include sadness (tristeza), droopy beak (pico caído), inappetence (no come), and loss of feathers (plumas caídas). Illnesses are predominantly associated with changes in weather or climatic conditions, as well as

Table 1 Household characteristics $(n=90)$

\begin{tabular}{llll}
\hline & & Frequency & Percentage \\
\hline Animal ownership & Chickens & 62 & 69 \\
& Ducks & 17 & 19 \\
& Swine & 8 & 9 \\
Transportation & Pickup truck & 8 & 9 \\
assets & Car & 13 & 14 \\
& Motorcycle & 24 & 27 \\
& Bicycle & 67 & 74 \\
Level of education & Illiterate & 16 & 18 \\
(head of household) & Primary school & 54 & 60 \\
& Secondary school & 9 & 10 \\
& Beyond secondary & 11 & 12 \\
& school & & \\
\hline
\end{tabular}


Table 2 Names and explanatory models for local illnesses in chickens, ducks, and swine

\begin{tabular}{|c|c|c|c|c|c|c|c|}
\hline & & Illness name ${ }^{a}$ & $\begin{array}{l}\text { System } \\
\text { Affected }\end{array}$ & Signs & Causes & Treatments & Source of health care \\
\hline \multirow[t]{8}{*}{ Chicken } & 1. & $\begin{array}{l}\text { Accidente por } \\
\text { abajo }\end{array}$ & Gastrointestinal & $\begin{array}{l}\text { Green diarrhea, inappetence, } \\
\text { droopy wings, }\end{array}$ & $\begin{array}{l}\text { Too much dust in the summer, } \\
\text { too much rain in the winter. } \\
\text { Unburied animals. }\end{array}$ & $\begin{array}{l}\text { Water with batteries, water with coins, } \\
\text { medicinal plants, tetracycline }\end{array}$ & $\begin{array}{l}\text { Home care, local stores, local } \\
\text { pharmacies. }\end{array}$ \\
\hline & 2. & $\begin{array}{l}\text { Accidente por } \\
\text { arriba }\end{array}$ & Respiratory & $\begin{array}{l}\text { Lethargy, inappetence, } \\
\text { droopy wings. }\end{array}$ & $\begin{array}{l}\text { Too much dust in the summer, } \\
\text { too much rain in the winter. } \\
\text { Unburied animals. }\end{array}$ & $\begin{array}{l}\text { No treatment. If treated, animal dies } \\
\text { faster. }\end{array}$ & Home care. \\
\hline & 3. & Apolio/polio & Neuromuscular & Crooked legs, cannot walk. & Unspecified disease targets legs & Medicinal plants, codeine & $\begin{array}{l}\text { Home care, local stores, local } \\
\text { pharmacies. }\end{array}$ \\
\hline & 4. & Calambres & Neuromuscular & Lethargy, feather loss, legs ache. & Warm weather. & Medicinal plants & Home-care \\
\hline & 5. & Cólera & Gastrointestinal & Diarrhea, lethargy, inappetence. & Weather changes. & Medicinal plants, loperamide & $\begin{array}{l}\text { Home-care, local stores, local } \\
\text { pharmacies. }\end{array}$ \\
\hline & 6. & Coriza & Respiratory & Swollen face, dyspnea & Weather changes, dust. & Tetracycline, amoxicillin, naproxen & $\begin{array}{l}\text { Home-care, local stores, local } \\
\text { pharmacies. }\end{array}$ \\
\hline & 7. & $\begin{array}{l}\text { Soco/pujo/ } \\
\text { moco }\end{array}$ & $\begin{array}{l}\text { Respiratory } \\
\text { disease }\end{array}$ & $\begin{array}{l}\text { Nasal discharge, lethargy, } \\
\text { inappetence }\end{array}$ & Weather changes. & $\begin{array}{l}\text { Tetracycline, unspecified eye drops, } \\
\text { other antibiotics, oil-soaked feather. }\end{array}$ & $\begin{array}{l}\text { Local stores, local pharmacies, } \\
\text { home-care. }\end{array}$ \\
\hline & 8. & Viruela/buba & $\begin{array}{l}\text { Systemic/ } \\
\text { cutaneous }\end{array}$ & $\begin{array}{l}\text { Hives, skin rash, blindness, } \\
\text { fallen feathers }\end{array}$ & $\begin{array}{l}\text { Wind carries microbes, mosquito bite, } \\
\text { crescent moon. }\end{array}$ & $\begin{array}{l}\text { Topical treatments involving heat } \\
\text { (with a nail or charcoal) and iodine, } \\
\text { chloride, or nail polish. }\end{array}$ & Home-care. \\
\hline \multirow[t]{8}{*}{ Duck } & 1. & Accidente & Systemic & $\begin{array}{l}\text { Lethargy, inappetence, green } \\
\text { diarrhea, hot ears }\end{array}$ & $\begin{array}{l}\text { Too much dust in the summer, } \\
\text { too much rain in the winter. } \\
\text { Unburied animals. }\end{array}$ & $\begin{array}{l}\text { No treatment. If treated, animal dies } \\
\text { faster. }\end{array}$ & Home care. \\
\hline & 2. & Mal de ojo & Systemic & Lethargy, green diarrhea & Drunken men, sweating people & $\begin{array}{l}\text { Red nail polish in the neck, } \\
\text { medicinal plants, isolation. }\end{array}$ & Home-care, traditional healers. \\
\hline & 3. & Soco/moquillo & $\begin{array}{l}\text { Respiratory } \\
\text { disease }\end{array}$ & $\begin{array}{l}\text { Nasal discharge, lethargy, } \\
\text { inappetence }\end{array}$ & Weather changes. & $\begin{array}{l}\text { Tetracycline, unspecified eye drops, } \\
\text { other antibiotics, oil-soaked feather. }\end{array}$ & $\begin{array}{l}\text { Local stores, local pharmacies, } \\
\text { home-care. }\end{array}$ \\
\hline & 4. & Buba & Cutaneous & $\begin{array}{l}\text { Hives, skin rash, blindness, } \\
\text { fallen feathers }\end{array}$ & Weather changes. & $\begin{array}{l}\text { Tetracycline, unspecified eye drops, } \\
\text { other antibiotics, oil-soaked feather. }\end{array}$ & $\begin{array}{l}\text { Local stores, local pharmacies, } \\
\text { home-care. }\end{array}$ \\
\hline & 5. & Calambres & Neuromuscular & Lethargy, feather loss, legs ache. & Warm weather. & Medicinal plants & Home-care \\
\hline & 6. & Coriza & Respiratory & Swollen face, dyspnea & Weather changes, dust. & Tetracycline, amoxicillin, naproxen & $\begin{array}{l}\text { Home-care, local stores, local } \\
\text { pharmacies. }\end{array}$ \\
\hline & 7. & $\begin{array}{l}\text { Accidente por } \\
\text { abajo }\end{array}$ & Gastrointestinal & $\begin{array}{l}\text { Green diarrhea, inappetence, } \\
\text { droopy wings, }\end{array}$ & $\begin{array}{l}\text { Too much dust in the summer, } \\
\text { too much rain in the winter. } \\
\text { Unburied animals. }\end{array}$ & $\begin{array}{l}\text { Water with batteries, water with coins, } \\
\text { medicinal plants, tetracycline }\end{array}$ & $\begin{array}{l}\text { Home care, local stores, local } \\
\text { pharmacies. }\end{array}$ \\
\hline & 8. & Apolio/polio & Neuromuscular & Crooked legs, cannot walk. & Unspecified disease targets legs & Medicinal plants, codeine & $\begin{array}{l}\text { Home care, local stores, local } \\
\text { pharmacies. }\end{array}$ \\
\hline Swine & 1. & Empacho & Gastrointestinal & Lethargy, inappetence hair loss & $\begin{array}{l}\text { Wind, weather changes, dust, lack of } \\
\text { vaccination. }\end{array}$ & Several antibiotics & Local pharmacies, home-care. \\
\hline
\end{tabular}


Table 2 Names and explanatory models for local illnesses in chickens, ducks, and swine (Continued)

2. Malde ojo Systeric Lethargy, green diarhea orunken men, sweating people

Systemic

Lethargy, green diarrhea

Drunken men, sweating people

Medicinal plants, isolation.

Home-care, traditional healers.

3. Parásitos

Gastrointestinal Diarrhea, lethargy, inappetence

Lack of vaccination, eating garbage.

Lard mixe

Home-care

Local pharmacies.

Contaminated water, lack of vaccination. Vitamins, anti-parasite medication. inappetence

${ }^{\mathrm{a}}$ Ilness names respect local terms 
with the presence of dust or dead animals. Treatments vary according to the predominant signs, with most illnesses treated with antibiotics and over-the-counter medications, some illnesses treated with local plants, and skin illnesses treated with topical procedures. Medications were procured primarily in local pharmacies and supply stores.

Illnesses in ducks are described very similar to those of chickens (Table 2), with the exception of the mal de ojo (evil eye), which is described in very similar terms as the syndrome amply described in humans [39]. Swine illnesses also include the mal de ojo, together with additional illnesses that present a combination of systemic, cutaneous, and gastrointestinal signs (Table 2). Perceived causes of illness, treatments, and help sought are similar to those described for chickens and ducks.

\section{Described illnesses, perceived causes, and treatments as identified by cross-sectional survey}

The most common illness reported to have occurred in the 15 days prior to the day of the household survey was soco, found in $56 \%$ of the households that raised chickens. Accidente was the most prevalent described illness in ducks (24\%) as was jiote in swine (50 \%). Table 3 shows reported illness prevalence by species. Nonspecific signs such as sadness (tristeza), inappetence (no come) and prostration (echado) were the most prevalent reported for each species, accounting for between 50 and $75 \%$ of the households. Importantly, these general signs were the ones reported as having being first noticed by survey respondents. This pattern remains when analyzing respiratory illnesses (soco, coriza) and gastrointestinal illnesses (colera, accidente por abajo), where non-specific signs were reported as being noticed initially and more frequently than syndrome defining signs. In contrast, for diseases of the skin, feather or cutaneous lesions were the first identified signs. Reported signs of illness are shown in Table 4.

Perceived causes of illness were predominantly (60$80 \%$ of reported illnesses) related to the physical environment and weather, such as temperatures warmer or cooler than normal, sudden changes in temperature, rain, and dust (Table 5). This pattern is even stronger for respiratory and gastrointestinal illnesses, where these climatic changes were perceived as the cause of up to $95 \%$ of reported cases. Unburied dead animals were also reported as a perceived cause, but only in $20-35 \%$ of cases. Skin illnesses were more often associated with non-weather related environmental contamination than were other illnesses but were also associated with dust due to changes in weather.

Diseases in both chickens and ducks were overwhelmingly treated with antibiotics obtained without prescription at local shops or pharmacies. Tetracycline and
Table 3 Frequency of illness ${ }^{a}$

\begin{tabular}{|c|c|c|c|}
\hline Species & $\begin{array}{l}\text { Households } \\
\text { reporting }\end{array}$ & Syndrome ${ }^{b}$ & $\begin{array}{l}\text { No. cases } \\
\text { reported }\end{array}$ \\
\hline \multirow[t]{10}{*}{ Chicken } & \multirow[t]{10}{*}{62} & Soco, pujo ó moco & 35 \\
\hline & & Viruela/buba & 22 \\
\hline & & Accidente & 16 \\
\hline & & Otras & 10 \\
\hline & & Accidente por arriba & 8 \\
\hline & & Coriza & 7 \\
\hline & & Accidente por abajo & 7 \\
\hline & & Apolio/polio & 5 \\
\hline & & Calambres & 5 \\
\hline & & Cólera & 3 \\
\hline \multirow[t]{9}{*}{ Duck } & \multirow[t]{9}{*}{17} & Accidente & 4 \\
\hline & & Otras & 4 \\
\hline & & Mal de ojo & 3 \\
\hline & & Soco o moquillo & 3 \\
\hline & & Buba & 2 \\
\hline & & Calambres & 2 \\
\hline & & Coriza & 1 \\
\hline & & Accidente por abajo & 1 \\
\hline & & Apolio/polio & 1 \\
\hline \multirow[t]{4}{*}{ Swine } & \multirow[t]{4}{*}{8} & Rasquiña o jiote & 4 \\
\hline & & Parásitos & 2 \\
\hline & & Empacho & 1 \\
\hline & & Mal de ojo & 1 \\
\hline
\end{tabular}

${ }^{a}$ Recall during the previous 15 days

${ }^{b}$ Illness names respect the local use of terms in Spanish

amoxicillin were the most commonly used antibiotics (Table 6). This was particularly true for respiratory and gastrointestinal illnesses such as soco, where $83 \%$ of cases were treated with tetracycline. The fewer number of reported disease cases in swine limited assessment of specific treatment frequency, however both antibiotics and changing the animal's diet were reported. The use of home remedies or medicinal plants was markedly less common. Treatment decisions were made in $90 \%$ of cases by the household itself and in most of the remaining $10 \%$ with the help of neighbors or relatives. Only two households reported having gone to a pharmacy or to a store specialized in animal products in the nearest city (Taxisco, $19 \mathrm{~km}$ from Monterrico, $22 \mathrm{~km}$ from Candelaria).

\section{Discussion}

Local terms and understandings of animal health problems pose challenges to the implementation of community-based surveillance programs because they highlight the knowledge and language gaps between 
Table 4 Households reporting signs of illness in the past 15 days, frequencies

\begin{tabular}{|c|c|c|c|c|}
\hline Local term & Translation $^{\text {a }}$ & $\begin{array}{l}\text { Chicken } \\
(N=62)\end{array}$ & $\begin{array}{l}\text { Ducks } \\
(n=17)\end{array}$ & $\begin{array}{l}\text { Swine } \\
(n=8)\end{array}$ \\
\hline Tristeza & Sadness & 45 & 10 & 2 \\
\hline No come & $\begin{array}{l}\text { Not eating, lack of } \\
\text { appetite }\end{array}$ & 40 & 18 & 6 \\
\hline Ronchas en la piel & Skin rash & 40 & 1 & 0 \\
\hline Postración, Echado & Prostration, recumbent & 37 & 17 & 3 \\
\hline Debilidad & Weakness & 37 & 7 & 1 \\
\hline Cuesta respirar & Difficulty to breath & 37 & 6 & 0 \\
\hline Mocos, flemas & Nasal discharge & 35 & 3 & 0 \\
\hline Ojos hinchados & Swollen eyes & 32 & 3 & 1 \\
\hline Alas caídas & Droopy wings & 31 & 7 & - \\
\hline Fiebre & Fever & 30 & 4 & 2 \\
\hline Cuesta caminar & Difficulty to walk & 29 & 9 & 1 \\
\hline Deshidratación & Dehydration & 29 & 5 & 2 \\
\hline Estornudos & Sneezing & 28 & 2 & 0 \\
\hline Tos & Coughing & 26 & 2 & 1 \\
\hline Secreciones oculares & Eye discharge & 25 & 2 & 1 \\
\hline Ciego & Blindness & 24 & 7 & 0 \\
\hline $\begin{array}{l}\text { Plumas caídas/pelo } \\
\text { caído }\end{array}$ & Fallen feathers/hair & 14 & 3 & 2 \\
\hline Piel hinchada & Swollen skin & 8 & 1 & 1 \\
\hline- & Other signs & 5 & 3 & 5 \\
\hline
\end{tabular}

a Likely translation to English of the local terms used in Spanish

institutional and community actors. The scientific underpinnings of infectious disease transmission and, especially, drivers for emergence of new zoonotic pathogens are unlikely to be well understood in communities with a low level of formal education unless translated into locally recognizable terms. This is reflected in the two rural communities involved in this study-over $75 \%$ of the population lacks secondary or higher education. This is exacerbated by the very limited public health and animal health resources available to the communities. This gulf in scientific understanding of infectious disease concepts and the language used to express these concepts between the formal public health sector and the communities most likely to first encounter an emerging zoonotic pathogen is an impediment to implementing community-based surveillance. However, this impediment can be markedly reduced by building bridges between what the community observes and how these observations can be translated into actionable public health information. This way, the challenge posed by local understandings of animal health problems is transformed into an opportunity for public health practitioners implementing epidemiological surveillance.
Table 5 Households reporting causes of illness in the past 15 days, frequencies

\begin{tabular}{|c|c|c|c|c|}
\hline Reported Cause ${ }^{a}$ & Translation & $\begin{array}{l}\text { Chicken } \\
(n=62)\end{array}$ & $\begin{array}{l}\text { Ducks } \\
(n=17)\end{array}$ & $\begin{array}{l}\text { Swine } \\
(n=8)\end{array}$ \\
\hline Calor & Hot weather & 27 & 6 & 1 \\
\hline $\begin{array}{l}\text { Cambios } \\
\text { de clima }\end{array}$ & Weather changes & 24 & 2 & 0 \\
\hline Polvo & Dust & 23 & 5 & 1 \\
\hline Verano & Summer & 22 & 3 & 2 \\
\hline Lluvia & Rain & 18 & 2 & 0 \\
\hline Virus & Virus & 16 & 5 & 1 \\
\hline Aire & Air & 16 & 3 & 1 \\
\hline Invierno & Winter & 16 & 2 & 0 \\
\hline Mosquito & Mosquito & 16 & 2 & 0 \\
\hline $\begin{array}{l}\text { Animals muertos } \\
\text { no enterrados }\end{array}$ & Unburied dead animals & 14 & 3 & 0 \\
\hline $\begin{array}{l}\text { Vendedores de } \\
\text { animales }\end{array}$ & Animal sellers & 9 & 3 & 0 \\
\hline Alimentos & Food & 4 & 0 & 2 \\
\hline $\begin{array}{l}\text { Sangre pesada, } \\
\text { energía fuerte }\end{array}$ & $\begin{array}{l}\text { III-natured person, } \\
\text { person with strong } \\
\text { energy }\end{array}$ & 1 & 3 & 0 \\
\hline Persona sudada & Sweaty person & 0 & 4 & 0 \\
\hline
\end{tabular}

\section{Early detection}

The community members clearly associate disease with changes in seasons and local weather patterns. This association is compatible with patterns of certain infectious diseases, including seasonal influenza. This is similarly relevant to the spread of new influenza viruses

Table 6 Households reporting treatment of illness in the past 15 days

\begin{tabular}{llll}
\hline Treatment & Chickens $(n=62)$ & Ducks $(n=17)$ & Swine $(n=8)$ \\
\hline Tetracycline & 57 & 9 & 3 \\
Other treatments & 36 & 6 & 3 \\
Amoxicillin & 22 & 2 & 1 \\
Battery water & 9 & 1 & 0 \\
Eye drops & 6 & 1 & 0 \\
Oil-soaked feather & 6 & 0 & 0 \\
Scrape the skin & 5 & 1 & 0 \\
lodine & 5 & 0 & 0 \\
Massage, rubbing & 4 & 3 & 0 \\
Medicinal bath & 2 & 1 & 0 \\
Isolation & 0 & 3 & 0 \\
Red nail polish & 0 & 1 & 0 \\
Rubbing with & 0 & 1 & 0 \\
medicinal plants & & 0 & 1 \\
Avoid certain foods & 0 & &
\end{tabular}


associated with seasonal migrations of wild waterfowl. Furthermore, the community members are observant in reporting initial, more general signs of disease, which strengthens their ability to detect early events. Understanding the local terminology and perceptions of animal health problems can aid public health practitioners in bridging the gaps that make it difficult to implement community-based surveillance programs.

\section{Diagnosis}

The public health community needs to understand diseases of epidemiologic priority in the context of endemic diseases as understood by local communities. Descriptive names may be linked to specific pathogens or, alternatively, be more generalized and encompass multiple pathogens unified only by initial presentation. Rabies for example, derived from the Latin for rage, has evolved from a syndromic description to represent a specific etiology that is commonly understood at both community and public health institutional levels. In contrast, "flu" denotes a specific etiology, influenza virus, at the public health level but may represent a variety of etiologies at the community level that have similar elements of clinical presentation. Providing diagnostic services focused on common illnesses in rural communities can define specific etiologies or sets of etiologies linked to the syndrome that would improve translation across educational divides, essentially focusing on education of public health professionals in the meaning of local terminologies rather than the reverse. By focusing diagnostic services on endemic diseases, the ability to detect a shift in disease signs, patterns, or affected species will be enhanced, a requirement for detection of a newly emergent pathogen.

\section{Treatment and prevention}

Importantly, diagnosis of disease must be accompanied by action, whether vaccination, treatment or changes in animal husbandry, in order to provide an incentive for reporting in community-based surveillance. Decisions about whether or not to treat an ill animal and with what were heavily influenced by neighbors rather than by animal health professionals. This in itself is unsurprising and is not necessarily linked to either level of education or socioeconomic status. For example, even in wealthy countries with available maternal health care services, expectant and new mothers seek and act on advice from experienced mothers among family and friends. However, there is also a need and opportunity for evidence-based information to be introduced into those familial and social networks [40]. This also applies to introducing the concept of infectious agents as a cause of disease. Attribution of disease causation only to climatic events, clearly not under the control of individuals or the community, inhibits the implementation of effective preventive measures, such as vaccination and animal husbandry. Use of the community engagement initiated during this study offers the opportunity to provide this information, especially to leaders within the community, and therefore take advantage of the existing community structure for dissemination.

Limitations of this study include those known for cross-sectional studies, and reliance on self-reported knowledge and behaviors. Results are only representative of the two studied villages.

\section{Conclusions}

Community-based surveillance of diseases of high epidemiologic priority is necessary and feasible. An estimated $60 \%$ of new human infectious diseases emerge from animals and the role of animals, especially swine, chickens, ducks, and migratory waterfowl, is well established for emergence and spread of new influenza viruses [5]. Although many zoonotic pathogens emerge in rural areas with a scarcity of either animal or human health services, they remain undetected until either affecting large numbers of people or animals or spreading to urban areas where detection capacity and capability exists. Enhanced community-based surveillance provides the opportunity to enable earlier detection and response by community-based recognition of a change in disease pattern and prompt notification of public health authorities. Understanding how communities view and express disease concepts, and engaging with them on their endemic disease problems, provides the opportunity to link their continuous observations and local knowledge to effect enhanced surveillance. Areas for future research include those aimed at designing participatory surveillance systems and measuring their effectiveness in disease control.

\section{Competing interests}

The author(s) declare that they have no competing interests.

\section{Authors' contributions}

$A C, M R O, D A$, and CC participated in study design. MRO and AC conducted data collection and data analysis for the ethnographic portion. AC conducted quantitative data analysis. AC, MRO, DA, GP, and CC participated in results interpretation. $A C$ drafted this manuscript while GP contributed specific sections and provided critical feedback on multiple drafts. MRO, DA, and CC also provided feedback on multiple drafts. AC, MRO, DA, GP, and CC have all reviewed and approved of the final manuscript.

\section{Acknowledgments}

We especially thank the community access and logistic support for data collection we received from Monterrico's and Candelaria's community councils. This study was supported by a Center for Disease Control and Prevention - Universidad del Valle de Guatemala Cooperative Agreement (No. 1U01GH000028-04 \& 1U01GH001003-01); research funds from University of Denver's Division of Arts, Humanities, and Social Sciences; Paul G. Allen; and the Scheumann Fund. 


\section{Author details}

'Center for Health Studies, Universidad del Valle de Guatemala, Guatemala City, Guatemala. ${ }^{2}$ Department of Anthropology, University of Denver, Sturm Hall Room 131, 2000 E. Asbury Ave, Denver, CO 80208, USA. ${ }^{3}$ Paul G. Allen School for Global Animal Health, Washington State University, Pullman, WA USA.

\section{Received: 21 October 2015 Accepted: 17 April 2016}

\section{Published online: 23 April 2016}

\section{References}

1. Iqbal M. Controlling avian influenza infections: The challenge of the backyard poultry. J Mol Genet Med. 2009;3(1):119-20.

2. Leboeuf A. The global fight against avian influenza: Lessons for the global management of health and environmental risks and crises, vol. 2. Paris: Institut Français des Relations Internationales; 2009. p. 119.

3. Mumford E, Bishop J, Hendrickx S, Embarek PB, Perdue M. Avian influenza H5N1: risks at the human-animal interface. Food Nutr Bull. 2007;28(2 Suppl):S357-63.

4. Van Kerkhove MD, Mumford E, Mounts AW, Bresee J, Ly S, Bridges CB, et al. Highly pathogenic avian influenza (H5N1): Pathways of exposure at the animal-human interface, a systematic review. PLoS One. 2011;6(1):e14582.

5. World Health Organization. Influenza research at the human and animal interface. Geneva: World Health Organization; 2006. p. 18. Report No.: WHO/ CDS/EPR/GIP/2006.3

6. Scalera NM, Mossad SB. The First Pandemic of the 21st Century: Review of the 2009 Pandemic Variant Influenza A (H1N1) Virus. Postgrad Med. 2009; 121(5):43-7.

7. Dawood FS, Iuliano AD, Reed C, Meltzer MI, Shay DK, Cheng P-Y, et al. Estimated global mortality associated with the first 12 months of 2009 pandemic influenza A H1N1 virus circulation: a modelling study. Lancet Infect Dis. 2012;12(9):687-95.

8. Chen H, Li Y, Li Z, Shi J, Shinya K, Deng G, et al. Properties and dissemination of $\mathrm{H} 5 \mathrm{~N} 1$ viruses isolated during an influenza outbreak in migratory waterfowl in western China. J Virol. 2006;80(12):5976-83.

9. Liu J, Xiao H, Lei F, Zhu Q, Qin K, Zhang XW, et al. Highly pathogenic H5N influenza virus infection in migratory birds. Science. 2005;309(5738):1206.

10. Kilpatrick AM, Chmura AA, Gibbons DW, Fleischer RC, Marra PP, Daszak P. Predicting the global spread of H5N1 avian influenza. Proc Natl Acad Sci. 2006;103(51):19368-73.

11. Li KS, Guan Y, Wang J, Smith GJD, Xu KM, Duan L, et al. Genesis of a highly pathogenic and potentially pandemic H5N1 influenza virus in eastern Asia. Nature. 2004;430(6996):209-13.

12. Ferguson NM, Cummings DA, Cauchemez S, Fraser C, Riley S, Meeyai A, et al. Strategies for containing an emerging influenza pandemic in Southeast Asia. Nature. 2005:437(7056):209-14.

13. Swayne DE, Akey BL. Avian influenza control strategies in the United States of America. Frontis. 2005:8:113-30.

14. Peiris JM, De Jong MD, Guan Y. Avian influenza virus (H5N1): a threat to human health. Clin Microbiol Rev. 2007:20(2):243-67.

15. Food and Agriculture Organization. FAO guidelines for surveillance of pandemic $\mathrm{H} 1 \mathrm{~N} 1 / 2009$ and other influenza viruses in swine populations. Rome: Food and Agriculture Organization of the United Nations; 2010.

16. Food and Agriculture Organization, International Livestock Research Institute. A manual for practitioners in community-based animal health outreach (CAHO) for highly pathogenic avian influenza. Geneva: Food and Agriculture Organization of the United Nations; International Livestock Research Institute; 2012.

17. Fouchier R. Animal influenza virus surveillance. Vaccine. 2003:21(16):1754-7.

18. Menéndez EL, Spinelli HG. Participación social: ¿para qué? Argentina: Lugar Editorial; 2006

19. Morgan LM. Community participation in health: perpetual allure, persistent challenge. Health Policy Plan. 2001;16(3):221-30.

20. Rifkin SB, Pridmore P. Partners in planning: information, participation and empowerment. London: Macmillan Education Ltd.; 2001.

21. Mariner JC. Manual on participatory epidemiology: methods for the collection of action-oriented epidemiological intelligence. Rome: Food and Agriculture Organization of the United Nations; 2000. p. 81.

22. Khan FM. Participatory appraisal and scanning surveillance based contagious diseases risk profile of district Rahim Yar Khan (Pakistan). Pak Vet J. 2010;30(4):198-202.
23. Hussain M, Malik MA, Fatima Z, Yousaf MR. Participatory surveillance of livestock diseases in Islamabad capital territory. Int J Agric Biol. 2005; 7:567-70

24. Socheat D, Chanta N, Setha T, Hoyer S, Chang MS, Nathan M. The development and testing of water storage jar covers in Cambodia. Dengue Bul. 2004;28(sSuppl). Available from: http://www.who.int/iris/handle/10665/ 163990.

25. Mariner JC, House JA, Mebus CA, Sollod AE, Chibeu D, Jones BA, et al. Rinderpest eradication: Appropriate technology and social innovations. Science. 2012;337(6100):1309-12.

26. Mariner JC, Catley A, Zepeda C. In: Sones K, Catley A, editors. The role of community-based programmes and participatory epidemiology in disease surveillance and international trade. Primary animal health care in the 21st Century: shaping the rules, policies and institutions Proc International Conference. 2002. p. 15-8. Available from: http://www.eldis.org/fulltext/ cape_new/mombasaconference/Mariner_et_al_PE_DiseaseSurveillance\% 26InternationalTrade.pdf.

27. Catley A, Leyland T. Community participation and the delivery of veterinary services in Africa. Prev Vet Med. 2001:49(1):95-113.

28. Catley A, Osman J, Mawien C, Jones BA, Leyland TJ. Participatory analysis of seasonal incidences of diseases of cattle, disease vectors and rainfall in southern Sudan. Prev Vet Med. 2002:53(4):275-84.

29. Azhar M, Lubis AS, Siregar ES, Alders RG, Brum E, McGrane J, et al. Participatory disease surveillance and response in Indonesia: strengthening veterinary services and empowering communities to prevent and control highly pathogenic avian influenza. Avian Dis. 2010;54(s1):749-53.

30. Ameri AA, Hendrickx S, Jones B, Mariner J, Mehta P, Pissang C. Introduction to participatory epidemiology and its application to highly pathogenic avian influenza participatory disease surveillance: A manual for participatory disease surveillance practitioners. 2009. Available from: https://cgspace.cgiar. org/bitstream/handle/10568/367/BirdFlu-Manual?sequence=2.

31. International Livestock Research Institute. Introduction to participatory epidemiology and its application to highly pathogenic avian influenza participatory disease surveillance: A manual for participatory disease surveillance practitioners. Kenya: Food and Agriculture Organization and International Livestock Research Institute; 2009.

32. Secretaría de Planificación y Programación de la Presidencia. Mapas de Pobreza. Secretaria General de Planificacion Economica y Social. 2006.

33. Consejo Municipal de Taxisco, Secretaría de Planificación y Programación de la Presidencia. Plan de desarrollo Taxisco, Santa Rosa, Guatemala. Guatemala: Secretaría General de Planificación; 2010.

34. Instituto Nacional de Estadística. Censo Nacional XI de Población y VI de Habitación: lugar poblado por Departamento y Municipio de Santa Rosa. (2002). Guatemala: INEFNUAP; 2002

35. Eisermann $\mathrm{K}$, Avendaño C. Evaluation of waterbird populations and their conservation in Guatemala. Waterbirds Conserv Am. 2006. Available from: http://avesdeguatemala.org/Waterbirds_GUA_final_20march2006.pdf

36. De Micheo RS, Fundación Defensores de la Naturaleza. Informe de conteos de anátidas en Guatemala. Available from: http://www.ducks.org/media/ Conservation/Conservation_Documents/_documents/Resumen\%20 Conteos\%20GT\%202006-2007\%20Final.pdf

37. Scrimshaw S, Hurtado E. Rapid assessment procedures for nutrition and primary health care. Tokyo: The United Nations University; 1987.

38. Bernard HR. Research methods in anthropology: qualitative and quantitative approaches. Lanham: AltaMira Press: 2011

39. Weller SC, Baer RD, de Alba Garcia JG, Glazer M, Trotter R, Salcedo Rocha AL, et al. Variation and persistence in latin american beliefs about evil Eye. Cross-Cult Res. 2015;49(2):174-203.

40. Nolan S, Hendricks J, Towell A. Social networking sites (SNS); exploring their uses and associated value for adolescent mothers in Western Australia in terms of social support provision and building social capital. Midwifery. 2015. Available from: http://www.sciencedirect.com/science/article/pii/ S0266613815001503 